\title{
The News Construction of Women in Online Media Tirto.Id About Cases of Sexual Abuse
}

\author{
Bunga Wahyu Kartikasari ${ }^{1}$, Arif Wibawa ${ }^{2}$, Prayudi ${ }^{3}$ \\ ${ }^{1}$ Tribun Jogja \\ J1. Jenderal Sudirman 52, Yogyakarta, Gondokusuman, Kota Yogyakarta, \\ Daerah Istimewa Yogyakarta 55223, Indonesia \\ Program Studi Ilmu Komunikasi, Universitas Pembangunan Nasional "Veteran" Yogyakarta \\ J1. Babarsari 2, Tambakbayan, Yogyakarta 55281, Indonesia \\ Email: bunga.kartikasari92@gmail.com ${ }^{1^{*}}$; wibawaarif@yahoo.com ${ }^{2}$; prayudi73@gmail.com ${ }^{3}$ \\ *corresponding author
}

\begin{abstract}
There are many mass media in Indonesia which is not implementing the concept of equality gender yet, especially news about sexual harassment. This research focuses on the news framing in online media Tirto. $i d$ under the hashtag sexual harassment. Constructivism theory is used in this research which is emphasized the reality is plural and subjective. The researcher takes 18 from 67 articles to be analyzed using Robert Entman's framing method. Entman's method focuses on four things, problems identification, casual interpretation, make moral judgment dan treatment recommendation. The result of this research is Tirto.id already implemented gender perspective journalism which was not brought the woman down but also didn't blame the men. Tirto.id constructs women like the one who's equal, smart and independent, but there's an inequality of gender between men and women. That's why women are kind of powerless that make them a victim of sexual harassment. For the news in the celebrity corner, Tirto.id tried to educate readers on how to respond to the sexual harassment. Meanwhile, in the non-celebrity corner, there are many critics said to the related institution as the way to enforce the concept of gender equality. This study provides recommendations in the form of policy proposals for online media to implement policies like Tirto.id's in delivering news, namely clear, bright, insightful, contextual, in-depth, factual and investigative like Tirto.id. Keywords: Framing Entman; Gender Equality; Online Media; Sexual Harassment; Tirto.id
\end{abstract}

\begin{abstract}
Abstrak
Ada banyak media massa di Indonesia yang belum menerapkan konsep kesetaraan gender, terutama berita tentang pelecehan seksual. Penelitian ini berfokus pada pembingkaian berita di media online Tirto.id bawah pelecehan seksual hashtag. Teori konstruktivisme digunakan dalampenelitian iniyang ditekankan kenyataannya adalah jamak dan subjektif. Peneliti mengambil 18 dari 67 artikel yang akan dianalisis menggunakan metode pembingkaian Robert Entman. Metode Entman berfokus pada empat hal, identifikasi masalah, interpretasi kasual, membuat penilaian moral dan rekomendasi pengobatan. Hasil penelitian ini adalah Tirto.id menerapkan jurnalisme perspektif gender yang tidak menurunkan wanita itu tetapi juga tidak menyalahkan para pria. Tirto. id membangun wanita seperti orang yang sama, cerdas dan mandiri, tetapi ada ketidaksetaraan gender antara pria dan wanita. Itu sebabnya wanita cenderung tidak berdaya sehingga membuat mereka menjadi korban pelecehan seksual. Untuk berita di sudut selebriti, Tirto.id mencoba mendidikpembaca tentang cara menanggapi pelecehan seksual. Sementaraitu, di sudutnon-selebriti, ada banyak kritikus mengatakan kepada lembaga terkait sebagai cara untuk menegakkan konsep kesetaraan gender. Penelitian ini memberikan rekomendasi dalam bentuk usulan kebijakan untuk media online agar menerapkan kebijakan seperti Tirto.id dalam menyampaikan berita, yaitu jelas, cerah, berwawasan, kontekstual, mendalam, faktual dan investigatif seperti Tirto.id. Kata kunci: Framing Entman; Kesetaraan Gender; Media Online; Pelecehan Seksual; Tirto.id
\end{abstract}

\section{Introduction}

The gender issue often becomes a part of this country's problem. The main subject isn't that far from a striking gap between men and women which was already happened from a long time ago. The hundred years of culture declares men will always be a winner in every lines and women are in the number two. This happens because Indonesia adheres the patriarchal pattern. Men will be a winner and women do 
the domestical work. Plus, the understanding of gender and sex sometimes mixes up, making the gender reconstruction is kind of difficult.

To resolve this problem, the mass media should produce news that support gender reconstruction. Why do the media become the important point? This refers to the Mass Media Theory which once said by Denis McQuail. According to him, media can inform news from the people. The media play a role as an agent of developing culture. From the media, people can get new cultures, like a lifestyle or the current trends (McQuail, 2011: 32).

All the time, the mass media often belittled women's fate and issues. Especially, the tendency of mass media follows patriarchal pattern and take sides to the male taste. Of the many reports that weakened female victims in cases of sexual abuse, there is one online media that actually echoes gender equality. Tirto.id does not follow the way of the seniors by making bombastic titles and clickbait to satisfy the audience's thirst for information or scooping up coffers of money.

Tirto.id which is still young often makes one article long enough. It's similar to the article when they made news of the sexual abuse of dangdut singer Via Vallen. Known by Jakarta's soccer players, Marco Simic is alleged to have sexually harassed singer Via Vallen. Simic gave a direct message to Via asking him to spend the night together with sexy clothes. Two days after the Via Vallen case boomed, Tirto.id just released a paper related to the case, which of course was outdated by other media. Tirto.id does not prioritize speed, but in-depth writing with journal adaptations to direct interviews with dangdut music experts.

Studies on news construction on the issue of sexuality has been very dynamic. Some studies focus on the news on gender and sexuality (Ferfolio, 2018), news on sexual politicization (Scheneidem \& Hannem, 2019), and narrative construction of social violence. However, issue on news construction on sexual harassment are still scarce. It is the gap that this study wants to fill.
The benefit of this research is to increase the understanding of media crews and journalists regarding news that carries the concept of gender equality. The researcher used constructivism theory and Robert Entman's framing method to find out the Tirto.id news frame related to the case. Research with Robert Entman's conception means that framing referred to giving definitions, explanations, evaluations and recommendations in a discourse to emphasize a particular frame of mind for events that are discourse. The four elements of Entman are define problems (defining problems), diagnose causes (estimating causes of problems), make moral judgment (making moral choices) and treatment recommendations (emphasizing completion). Meanwhile, constructivism theory has its own views on the media and the news text that it produces. First introduced by Peter L. Berger and Thomas Luckman, constructivism theory initially refers to the human person who is a product of society. For Berger, reality was not formed scientifically, but could be reconstructed. With this understanding, reality could be doublefaced and even plural. Everyone has a different construction of reality (Eriyanto, 2012: 15), so this research aims to find out the Tirto.id news frame related to sexual harassment cases that afflict celebrity and non-celebrity women.

\section{Research Methods}

This study adopted the qualitative research method. Theories in the qualitative tradition mean looking for ideas or ideas written by experts in books, journals, or other publications. Descriptive research aims to explain social systems, events, or social relations. It explains the phenomena with scientific thinking rules that are applied systematically or normatively by holding a classification, standard assessment of norms, the relationship, and position of an element with other elements. The use of theory in the qualitative tradition is as an initial confirmation that there is scientific written evidence on a topic that has 
been studied and studied (Semiawan, 2010: 105).

In this study, the object of his research was news about women as victims of sexual harassment in Indonesia on the Tirto.id media. In the period February 2016 to November 2018, Tirto.id uploaded 157 news on the Sexual Harassment tag. However, researchers did not take all the news. The researcher chose the news that fit the theme, namely sexual abuse of celebrity and non-celebrity women in Indonesia, so that the articles used in this study only reached 67 news stories from January to November 2018.

The argument for the selection of Tirto. $i d$ is due to the uniqueness of this publication compares to others. In terms of uploading news, Tirto.id emphasizes more on accuracy rather than the speed of uploading news. Tirto. $i d$ also frames coverage in various types, such as hard news, soft news, and features. The data collection technique from this study was a qualitative technique. According to Suryabrata (2016: 38), qualitative data processing techniques took place in several stages, namely, selection, analysis, and interpretation.

The data gathering included news of sexual abuse of celebrity women and non-celebrities in Indonesia at Tirto.id. This method is known as documentation. According to Arikunto (2006: 158), documentation is to find and collect data on matters in the form of notes, transcripts, books, newspapers, magazines, minutes, report cards, and agendas. From the 157 news collected in sexual harassment tags, there were 67 news items selected for investigation from January to October 2018. The news was a case of female sexual abuse in Indonesia, with details of 62 news on non-celebrity women and five celebrity news.

The study deliberately chose that period as there had been numerous reporting of news about women who became victims of sexual abuse in Indonesia. However, the study did not analyze all news. It used a random system to select news concerning sexual harassment of women. The study had used the random. org website service to ensure the random process took place, which then gave 12 noncelebrity reports through the randomizer list.

In this study, the researcher used triangulation source and theory, namely utilizing different types of data sources to explore similar data and to examine a theory in discussing the problems studied (Moleong, 2014: 331). Then, the principle of framing analysis said that there was a process of selection and sharpening of certain dimensions of the facts reported by the media. Data was collected from Tirto. id by researchers, then the data was used for coding sheets. News that had been selected was then analyzed by Robert Entman's framing device. Entman views framing in two large dimensions which emphasize selection of issues and emphasize certain aspects of reality. Prominence meant in the process of making information more meaningful, more interesting so that it is easily remembered by the audience.

\section{Results of Research and Discussion}

Most news of sexual abuse of celebrity and non-celebrity women uploaded by Tirto. id were framed in such a way as to support victim and impose sanction on related actors or institutions. This was the result of implementating constructivist theory by Peter L. Berger and Thomas Luckman. Both of them thougts, the reality wasn't scientifically formed, it's the result of the reconstruction. It meant, multiple-faced reality was even plural. Everyone had different construction of reality.

In the study of communication, proponents of social construction theory assumed that society was structurally, ideologically, powerfully and culturally made by human. Tirto.id then used the theory to reconstruct new realities that might be unpopular, namely reality based on gender equality. Because the news of sexual abuse of women in the media rarely supported the victim, especially if the victim was a celebrity. Some of the assumptions that were believed to influence 
this were because the media chain of activities tends to be dominated by men. In other words, all products were in accordance with the views and tastes of men, so that women were easily made into commodities (Juditha, 2015: 10).

Subono (2003: 12-17) one said that gender perspective journalism meant promoting the means to free and empower marines, such as women. For him, media was a tool that must be used by women to carry out the concept of gender equality. Then, the results of the coverage reflect the ideology of journalists who were genderminded using gender-sensitive language and clarity of bias (Murtiningsih \& Advenita, 2017).

In the news of celebrities Via Vallen and Gita Savitri for example, Tirto.id supports both of them to speak while tucking in a number of quotes from speakers who promote gender equality. It is known that a gender perspective media is a media that sees economic, social, political and cultural problems by not distinguishing between men and women. That is, if there is a problem, it does not bring down one of the parties and does not identify a particular gender towards gender roles specifically (Haryanto 2013: 1).

Tirto.id also intentionally attached a number of national statements that contradicted what Via did. Instead of supporting them, they mocked Via as a woman who sought attention and sold expensive to the handsome Marko Simic. It became Tirto.id's footing to write down some of the nation's problems that tended to get used to sexual harassment. There are a number of schemes that you want to appear in this article. First, against Warganet regarding the attitude of Via who reported sexual abuse. Second, the image of women in the dangdut universe. Third, the difference between Via Vallen and previous singers and the invitation of Tirto.id to support Via talked about sexual abuse cases that they experienced.

In the third scheme, Tirto.id helped construct the figure of Via Vallen as a victim of sexual harassment that is not worthy of corner, even though he is a dangdut singer who is synonymous with rocking. However, Tirto.id also did not necessarily construct Marco Simic as a harasser. Because, Via herself did not report the incident to the authorities, so Tirto.id did not want to go against the flow of law. That way, Tirto.id chose to educate the public with the concept of correct gender reconstruction.

The day after the coverage of Via Vallen, Tirto. $i d$ began to aggressively invite readers, especially women, to speak up if they were sexually abused like Via Vallen. The researcher saw, Tirto.id considered what the Via did was right and good if it was copied by her fans. Naturally, readers will follow the style of celebrities, not only through actions but also words. That way, the community no longer teaches sexual harassment to women.

As Burrhus Frederic Skinner said in 1940, the Stimulus-Organism-Response (SOR) theory is the basis of why many fans follow their idols. In liking a celebrity and making it a model is normal from the development of identity in childhood and adolescence (Yue \& Cheung, 2000: 91). The worship of celebrities is influenced by habits such as seeing, hearing, reading and learning about the lives of celebrities in excess to create identical traits (Maltby et al, 2004: 411-428).

Likewise with the case that happened to Hilda, the ex-wife of Kriss Hatta. Tirto.id firmly stated that what Kriss did was disgusting and the word was written by the editor as the title. In the Kriss case, Tirto.id also quoted warganet comments which tended to corner Kriss. This is done so that the perpetrator knows what is done is not the right thing and has entered the realm of abuse. The moral value offered by Tirto.id in that case is asking victims not to be ashamed to ask for help if they experience revenge porn from irresponsible men. Meanwhile, for the solution to the problem, Tirto.id equates to the case that befell Via and Gita, namely reporting to the authorities.

In this case, Tirto.id openly constructed Kriss Hatta as the perpetrator of porn revenge. How Kriss Hatta committed violence that 
attacked a person's psychological integrity. Tirto.id described Kriss as a disgusting person who often sought trouble with his ex-wife. No responsibility, Tirto.id accused Kriss of being ignorant of the humanity and dignity of women. Kriss is considered to have made Hilda a used item of hers which perpetuates gender-based violence.

Unfortunately, in the realm of celebrity news Tirto.id does not interview the celebrity directly, so readers do not really know what celebrities feel when they are sexually abused. Celebrity statements are taken from what they say on social media only.

In the realm of non-celebrity reporting, it appears that Tirto.id was annoyed in a way that was not harsh but very strong, emphasizing his upset attitude at the campus regarding sexual harassment. Most of the Tirto.id news raised cases of sexual abuse on campus where the victims were female students. This is done by Tirto.id because it considers campus to be a place where people with Intelligence Quotient (IQ) and Emotional Quotient (EQ) gather, but amoral cases still occur that should not occur.

Initially, Tirto.id often issued writings from journalist correspondence with female students who were victims of sexual abuse. Tirto.id invited the victims to tell journalist Adam Aulia to have evidence that the case could happen on campus. From the results of correspondence, dozens of students who were victims were willing to share their stories with journalists. From there, without publishing real names, journalists can share their stories with a wide audience and emphasize anyone out there to dare to resist abuse because they are not alone.

Then, the Agni student case appeared in the media in October 2018 and became a topic of discussion for almost everyone. Through a series of news from Agni, Tirto.id continued to criticize the campus policy which was considered slow in handling the 2017 case. Editorial Tirto.id assesses the campus has the responsibility to solve the problem of sexual abuse because the perpetrator is a university academic community.
It was noted, there were five published news sequentially urging the campus to immediately resolve cases of sexual abuse. The title is varied, but the angle chosen is almost the same, urging the university to immediately resolve the immoral case. In urging, Tirto.id borrowed many opinions from sources, such as BEM, experts to ministers. The news uploaded in a coherent manner can affect people's thinking. In noncelebrity news, not all news is written in feature style by Tirto.id, considering there are many news updates. However, even on hard news, Tirto.id also continues to frame the news with a gender perspective. Infographics are also not presented in all non-celebrity news by Tirto.id.

In the selection of speakers, Tirto.id chose people at LBH, lecturers who focused on gender equality and a number of anti-sexual harassment organizations to provide opinions, supported their vision of criticizing the campus. In fact, Tirto.id deliberately issued an article entitled 'Campus Becomes Fertile Land for Sexual Harassment Cases' to corner the university that was not immediately aware of the case. Even so, the news is written in a feature style, so the university cannot be angry but still cannot refuse because of the data contained.

This was also done by Tirto.id in the news of the Baiq Nuril teacher who was sentenced to prison by the Supreme Court for recording indecent conversations of the principal who harassed him. In this case, Tirto.id was able to interview Baiq Nuril exclusively to channel Baiq's feelings after he was sentenced to prison. The news was then written in the form of question and answer without reducing empathy for Baiq.

News that carries gender equality can be seen from the style of Tirto.id writing cases of sexual abuse at the National Hospital. In the three stories studied, Tirto.id did not necessarily corner nurses J, suspected sexual harassers. However, they still use the principle of presumption of innocence, where the perpetrators do not necessarily do it because there are indications 
that the victim is unconscious and hallucinating. It was seen from the news of the disagreement of the medical associations in Yogyakarta, Solo, and Semarang over the detention of J. Maka nurses, Tirto.id framed the news with the aim of reducing sexual harassment in hospitals alone.

Based on the results of the framing analysis. Tirto.id has positioned itself as a media that has a gender perspective in its reporting. All news released by Tirto are not gender bias, supporting victims to speak and provide information to the public that sexual harassment must be fought for a better life.

Overall, Tirto.id considers women to be equal to men, intelligent and independent. Women have the right to higher education, decent jobs and even work in the public sphere. However, those who experience sexual abuse are mostly in unequal power relations, which makes women not more empowered than men, like the Baiq Nuril case for example. The unequal relationship of power comes from a patriarchal culture that has taken hundreds of years in this country. The existence of such inequality then forced the victim to remain silent, if there was sexual harassment on him with the reason that he was afraid of having a long tide and fear of being blamed. The moral and religious context is also included in their thinking which results in better silence than being dragged into problems in the social environment.

This research was supported by Yudarwati Hayuningtyas's research in 2017. In a study entitled Construction of Women's News in Online Media (Rape News Framing Analysis Conducted by Sitok Srengenge Writers in Tempo and Republika Online Media for the November 2013 period), Yudarwati assessed that online media could not act neutral. In the study, Yudarwati found the fact that Tempo tended to cover up the incident that happened to Sitok because of his proximity to the writer. Meanwhile, Republika supports victims to discuss the rape case to the police so that the suspects can be given appropriate punishment.
According to the results of the analysis of researchers, Tirto.id is indeed not neutral because it supports many female victims to talk about sexual abuse cases that befall them. That way, women can get their rights in full.

Media can indeed play a central role in both communication and information tools, even education and socialization on various matters. What comes out in the news can cause negative or positive influence. Especially on gender issues that women are often seen as weak because they are not seen as important "things".

According to Nur Iman Subono (2003: 1215), journalists will be more gender sensitive if male and female journalists are "gendersensitized". Other factors such as the level of media professionals and journalists can also influence awareness of gender issues. The presence of training in gender awareness is therefore very important. Without gender awareness of the media and journalists, directly or indirectly the role is responsible for the occurrence, especially for women.

\section{Conclusion}

In sum, Tirto.id has adopted reporting policy that is to provide clear, enlightening, insightful, contextual, deep, investigative and factual information. The mission is clearly seen in reporting sexual harassment of women celebrities and non-celebrities. In the 17 articles studied, Tirto.id did not provide casual sexual abuse news. In fact, the existence of sexual harassment cases is a moment to rectify the reader mindset. Both in the news of celebrities and non-celebrities, Tirto.id framed the news with the aim that the public would support the victims and not teach sexual harassment. Even so, Tirto.id did not immediately blame the perpetrators for harassing women. On celebrity news, Tirto.id frame it by slipping campaigns so that women dare to speak if they have been sexually abused. Not only that, by citing research and expert opinion, Tirto.id asked the community 
to correct the mindset so that the culture of teaching sexual harassment no longer occurred.

Meanwhile, on non-celebrity news, Tirto. id tends to urge the institution to provide justice to the victims. In Agni's case, Tirto. id explicitly framed the news saying UGM was slow to handle the case. The frame is also seen in Baiq Nuril. Meanwhile, in the case of Surabaya National Hospital, Tirto.id continued to apply the principle of presumption of innocence to nurses because the victims were still under the influence of anesthesia.

Broadly speaking, Tirto.id constructs women as independent and equal to men. The speed of uploading the news is indeed a prima donna for online media. However, Tirto.id does not need to follow the flow. Today, readers no longer need fast news because there is already social media. Informative and enlightening news is articles needed by the community. Tirto.id can be an agent of change in society because of its investigative and factual reporting. So, Tirto.id needs to maintain such a news style so that readers not only understand a problem at a glance, but are more comprehensive. This study provides recommendations in the form of policy proposals for online media to implement policies like Tirto.id's in delivering news, namely clear, bright, insightful, contextual, indepth, factual and investigative like Tirto.id.

\section{References}

Arikunto. (2006). Prosedur Penelitian Suatu Pendekatan Praktik. Jakarta: PT. Rineka Cipta.

Asquith, N. L., Ferfolia, T., Brady, B., \& Hanckel, B. (2019). Diversity and safety on campus@ Western: Heterosexism and cissexism in higher education. International review of victimology, 25(3), 320-340.

Eriyanto. (2001). Analisis Wacana: Pengantar Analisis Teks Media. Yogyakarta: LKiS.

Eriyanto. (2012). Analisis Framing: Konstruksi, Ideologi, dan Politik Media. Yogyakarta:
LKiS.

Haryanto, Ignantius. (2013). Jurnalisme di Era Digita: Tantangan Industri Media Abad 21. Jakarta: Penerbit Buku Kompas.

McQuail, Denis. (2011). Teori Komunikasi Massa McQuail, Edisi 6 Buku 1. Jakarta: Salemba Humanika

Moleong, L. (2014). Metodologi Penelitian Kualitatif. Edisi Revisi. Bandung: PT Remaja Rosdakarya.

Semiawan, Conny R. (2010). Metode Penelitian Kualitatif. Jakarta: Grasindo.

Suryabrata, Sumadi. (2016). Metodologi Penelitian. Jakarta: Rajawali Press.

Juditha, Christiany. (2015). Gender dan Seksualitas dalam Konstruksi Media Massa. Jurnal Simbolika: Research and Learning in Communication Study, 1(1), 6-15. https:// doi.org/10.31289/simbollika.v1i1.45

Maltby, John, Liza Day, Lynn E McCutcheon, Raphael Gillett, James Houran and Diane D Ashe. (2004). Personality and coping: A context for examining celebrity worship and mental health. The British Psychological Society, 95(4).

Murtiningsih, B. S. E., \& Advenita, G. E. M. (2017). Representation of Patriarchal Culture in New Media: A case study of News and Advertisement on Tribunnews.com. Mediterranean Journal of Social Sciences, 8(3), 143-154. $\quad$ https://doi.org/10.5901/ mjss.2017.v8n3p143

Hannem, S., \& Schneider, C. J. (2019). Stigma and the "Weinstein Effect". Building Sexual Misconduct Cases against Powerful Men, 11.

Subono, N. I. (2003). Menuju jurnalisme yang berperspektif gender. Jurnal Perempuan, 28, 60-64.

Yue, Xiao Dong \& Chau-kiu Cheung. (2000). Selection of favourite idols and models among Chinese young people: A study comparative study ini Hong Kong and Nanjing. The International Society for the Study of Behavioural Development Vol 24 (1): 91-98. 